\title{
THE STRUCTURE OF SUBTIDAL MACROALGAL ASSEMBLAGES AT THE TAMOIOS ECOLOGICAL STATION, A THREATENED CONSERVATION UNIT IN RIO DE JANEIRO, BRAZIL
}

\author{
Victor de Souza Koutsoukos ${ }^{* 1}$, Roberto Campos Villaça ${ }^{1}$ and Maria Teresa Menezes de Széchy ${ }^{2}$ \\ ${ }^{1}$ Universidade Federal Fluminense \\ (Rua Outeiro São João Batista, s/nº, 24001-970 Niterói, RJ, Brasil) \\ ${ }^{2}$ Universidade Federal do Rio de Janeiro \\ (Rua Professor Rodolpho P. Rocco 211, bloco A, 21941-902 Rio de Janeiro, RJ, Brasil) \\ *Corresponding author: vkoutsoukos@gmail.com
}

http://dx.doi.org/10.1590/S1679-87592015082606301

\begin{abstract}
A B S T R A C T
The structure of subtidal rocky bottom communities at Tamoios Ecological Station (TES), situated in Ilha Grande Bay, Rio de Janeiro State, as well as in other Brazilian marine protected areas, is insufficiently characterized. The present study describes the macroalgal assemblages of shallow subtidal rocky bottoms on two islands of the TES-Imboassica (IM) and Búzios Pequena (BP)adopting species and genera as observational units. Two sites were surveyed on each island in summer 2011. Random 30x30 cm quadrats $(n=3)$ were scraped to collect all macroalgae except crustose species. The subtidal assemblages, in which 58 macroalgal species occurred, were characterized by the high frequency and percent cover of Sargassum vulgare C. Agardh $(56.8 \pm 8.4 \%)$. The sites differed significantly in total number of species and Shannon-Weiner diversity index (PERMANOVA, $\mathrm{p}<0.05$ ). According to SIMPER, the macroalgal genera that most contributed to the dissimilarities of cover between the sites (contribution $>5 \%$ ) were Sargassum, Laurencia, Wrangelia, Canistrocarpus, Asparagopsis, Hypnea, Ceratodictyon, Gayliella, Spyridia and Chondria. Dissimilarities within and between the islands, as shown by nMDS of the cover data, suggest that different spatial scales should be considered in monitoring the rocky bottom communities of Ilha Grande Bay.
\end{abstract}

\section{RESUMO}

É insuficiente a caracterização da estrutura de comunidade de costões rochosos na Estação Ecológica de Tamoios (ESEC Tamoios), Baía da Ilha Grande, estado do Rio de Janeiro, assim como em outras unidades de conservação marinhas do Brasil. No presente estudo, foi descrita a assembleia de macroalgas do infralitoral raso de substrato rochoso em duas ilhas da ESEC Tamoios: Imboassica (IM) e Búzios Pequena (BP), utilizando-se espécie e gênero como unidades observacionais. Em cada ilha, duas localidades foram amostradas no verão de 2011. Quadrados de $30 \times 30 \mathrm{~cm}(\mathrm{n}=3)$, dispostos aleatoriamente, foram raspados para coletar macroalgas, excetuando-se as incrustantes. As assembleias do infralitoral, onde 58 espécies de macroalgas foram identificadas, foram caracterizadas pela alta frequência e percentagem de cobertura de Sargassum vulgare C. Agardh $(56,8 \pm 8,4 \%)$. As localidades foram significativamente diferentes no número total de espécies e no índice de diversidade Shannon-Weiner (PERMANOVA, $\mathrm{p}<0,05$ ). De acordo com SIMPER, os gêneros de macroalgas que mais contribuíram para as dissimilaridades entre as localidades (contribuição >5\%) foram: Sargassum, Laurencia, Wrangelia, Canistrocarpus, Asparagopsis, Hypnea, Ceratodictyon, Gayliella, Spyridia e Chondria. As dissimilaridades encontradas dentro e entre as ilhas, visualizadas por nMDS para dados de cobertura, apontam a necessidade de considerar diferentes escalas espaciais para o monitoramento das comunidades de costões rochosos da Baía da Ilha Grande.

Descriptors: Islands, Marine protected area, Rocky shores, Spatial variability.

Descritores: Ilhas, Unidade de conservação, Costões rochosos, Variabilidade espacial.

\section{INTRODUCTION}

Macroalgal diversity has been among the most important considerations in the establishment, management and monitoring of Brazilian marine protected areas (OLIVEIRA FILHO; UGADIM, 1976; SZÉCHY et al., 1989; FALCÃO et al., 1992; FIGUEIREDO et al., 2004; AMADO FILHO et al., 2006; HORTA et al., 2008; MACHADO et al., 2011). In Brazil, protected areas are defined as territorial 
spaces with relevant natural features, including jurisdictional waters, which are legally established by government authorities under special regulation and must be appropriately protected by environmental agencies (Law no 9.985; BRASIL, 2000).

In Ilha Grande Bay (on the southern coast of Rio de Janeiro State), eleven protected areas have been established, of which the Tamoios Ecological Station (TES) contains the largest marine area under full protection. The TES was established as a Wholly Protected Conservation Unit by Federal Decree no 98.864 (BRASIL, 1990). Despite governmental efforts to manage the protected areas of Ilha Grande Bay, multiple anthropogenic disturbances threaten its marine environment (CREED et al., 2007). Due to its magnificent natural beauty, this embayment has attracted substantial commercial activity, which has occupied mountain slopes, river margins and mangrove forests in the area and resulted in deforestation and marine pollution (ALHO et al., 2002). Other potential impacts to Ilha Grande's marine ecosystem include the Angra dos Reis harbor, BrasFels dockyard, PETROBRAS oil depot (TEBIG) and Almirante Álvaro Alberto nuclear power station.

Rocky shores are among the most threatened marine habitats in Ilha Grande Bay. For example, changes in community structure have been reported for subtidal rocky bottoms because of the establishment of nonnative species such as the ahermatypic corals Tubastraea coccinea Lesson, 1829, and T. tagusensis Wells, 1982 (LAGES et al., 2011), and the green seaweed Caulerpa scalpelliformis ( $\mathrm{R}$. Brown ex Turner) C. Agardh (FALCÃO; SZÉCHY, 2005). In addition to invasion by nonnative species, other factors have been recognized as threats to rocky bottom communities, including habitat loss, modification of coastal processes, overharvesting and contamination (CLYNICK et al., 2009).

The importance of macroalgal diversity to the structure of rocky shore communities has been illustrated by STACHOWICZ et al. (2008) and LANARI and COUTINHO (2014). Macroalgae are important contributors to rocky shore diversity, providing many marine species with habitat, food and protection against predators (WAHL, 2009). These contributions notwithstanding, macroalgal diversity remains a relatively neglected topic (NORTON et al., 1996) in many marine protected coastal areas of Brazil. Although several relevant studies have been conducted in the protected areas of Ilha Grande Bay (FALCÃO et al., 1992; FIGUEIREDO et al., 2004; FIGUEIREDO; TÂMEGA, 2007), data regarding the structure of the rocky bottom communities of the islands that comprise the TES, where seaweeds are the dominant organisms, are limited. This gap, as indicated by GOODSELL and UNDERWOOD
(2009), prevents the formulation of effective conservation strategies for these habitats. Furthermore, spatial descriptions of marine communities are needed to appropriately design reserves to include sites that are representative of, or unique to, specific areas (AIRAME et al., 2003).

Therefore, in addition to identifying the macroalgae from the shallow subtidal rocky bottoms of islands in the TES, this study aimed to describe the structural patterns of the macroalgal assemblages and analyze the similarities among different sites.

\section{Material And Methods}

\section{Study Area}

The TES is situated within Ilha Grande Bay, southern Rio de Janeiro State, Brazil (22 $58^{\prime}$ $23^{\circ} 12^{\prime} \mathrm{S}$ and $\left.44^{\circ} 17^{\prime}-44^{\circ} 41^{\prime} \mathrm{W}\right)$. On the subtidal rocky bottoms of Ilha Grande Bay, macroalgae and sessile macroinvertebrates, such as Palythoa caribaeorum (DUCHASSAING and MICHELOTTI, 1860) and Zoanthus sociatus (ELLIS, 1768), compete for substrate (CREED, 2009).

The macroalgal assemblages of shallow (2-4 $m$ deep) subtidal rocky bottoms were assessed on two islands: Imboassica (IM) and Búzios Pequena (BP). Two sites were surveyed on each island, to a total of four, in summer 2011: IM1, IM2, BP3 and BP4 (Fig. 1 ). The sites were randomly selected from among ten sites that had previously been defined around each island.

IM is located in the Central Channel, and BP is located in the West Zone, two different areas of Ilha Grande Bay defined according to their physiographic and bathymetric features (MAHIQUES; FURTADO, 1989). IM has a perimeter of $1.43 \mathrm{~km}$ and a maximum depth of $25 \mathrm{~m}$, and BP has a perimeter of $0.82 \mathrm{~km}$ and a maximum depth of $21 \mathrm{~m}$; both islands are surrounded by granitic rocky shores.

Both islands are less than $6.5 \mathrm{~km}$ from the nearest continental coast, and are about $8.5 \mathrm{~km}$ apart. The two sites at IM are separated by approximately $500 \mathrm{~m}$; at BP, the two sites are $220 \mathrm{~m}$ apart. Two sites (IM1, BP3) are northern orientated (shoreward), whereas IM2 and BP4 are southern (seaward) and western orientated, respectively. The entrance of waves from the S-SE quadrant into Ilha Grande Bay is facilitated by the coastline configuration of the embayment, as reported by BELO (2002), and waves arriving from other quadrants are partially or totally obstructed. Therefore, regarding wave exposure, we considered IM1 and BP3 as protected sites and IM2 and BP4 as moderately exposed. 


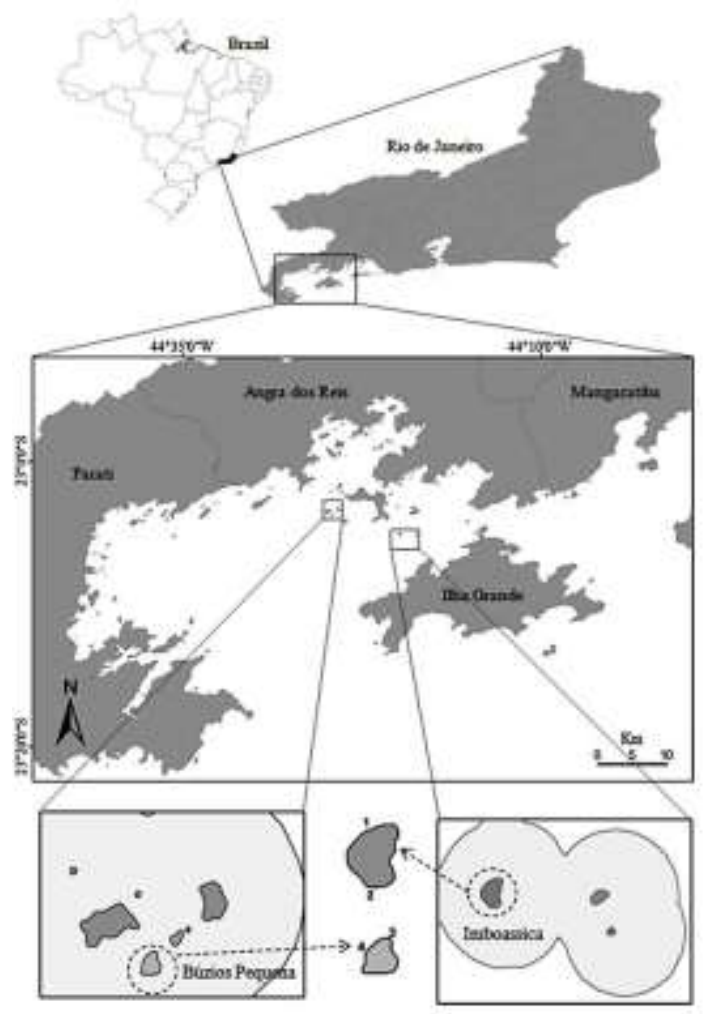

Fig. 1. Map of Brazil, Rio de Janeiro State, and localization of the Ilha Grande bay, indicating Tamoios Ecological Station's islands and the sampling sites: Imboassica Island (IM, sites 1 and 2) and Búzios Pequena (BP, sites 3 and 4).

Field and Laboratory Methodologies

At each site, a single depth zone $(2-4 \mathrm{~m})$, as characterized by macroalgal assemblages, was sampled with $30 \times 30 \mathrm{~cm}$ quadrats placed randomly along a $10 \mathrm{~m}$ transect $(\mathrm{n}=3)$. Sampling was performed by SCUBA diving and using a chisel to scrape the substrate within the quadrats. Coralline crusts were not sampled. Later, all samples were fixed in seawater with $4 \%$ formalin.

In the laboratory, the samples were carefully analyzed under stereoscopic and optical microscopes. Macroalgae were identified to the finest taxonomic resolution possible based on floristic surveys for the western Atlantic Ocean, mainly those of JOLY (1965), SCHNEIDER and SEARLES (1991), LITTLER and LITTLER (2000) and DAWES and MATHIESON (2008). The cover of each species or species group was estimated, after plunging each one in a bowl of water, by vertical projection over a paperboard of $30 \times 30 \mathrm{~cm}$ divided into 100 quadrats $(1 \times 1 \mathrm{~cm})$. The cover of the most conspicuous macroalgal epiphytes was estimated as follows: for each quadrat, the cover of each epiphytic species/genus was calculated as the product of its cover on the macroalgal basibionts and the total cover of those basibionts, considering the areas occupied by the vertical projection over the paperboard. Species with negligible cover received an arbitrary value $(0.05 \%)$. Therefore, the total cover represented macroalgae occurring at three different layers - the epiphytic layer, canopy and understory, in which different species grew together as an entangled cushion or turf - and in all cases exceeded $100 \%$.

Analytic and synthetic parameters were calculated based on the methods of VILLAÇA et al. (2008). Analytic parameters were as follows: total number of species $(\mathrm{Nt})$ - number of species within a quadrat; cover $(\mathrm{C} i)$ - percentage cover of species $i$ within a quadrat; total cover $(\mathrm{Ct})-$ sum of $\mathrm{C} i$ for all species within a quadrat; Shannon-Weiner diversity index (H') and Pielou's evenness index (J'). Synthetic parameters were as follows: frequency of occurrence (Fi) and mean cover $(\mathrm{Cm} i)$ of species $i$ considering all of the quadrats studied. 
Statistical Analysis

Univariate permutational analysis of variance (PERMANOVA) was used to investigate significant differences among the sites regarding $\mathrm{Nt}$, $\mathrm{Ct}, \mathrm{H}^{\prime}$ and J'. A posteriori pairwise comparisons were used to determine significant differences among the sites. All univariate tests were based on Bray-Curtis similarity matrices generated from the untransformed data and 999 permutations.

To evaluate the structural patterns of the macroalgal assemblages, nonmetric multidimensional scaling (nMDS) based on Bray-Curtis dissimilarities was applied to the macroalgal genera cover (untransformed data). The data matrix for this analysis considered 44 variables and 12 sampling units. For each quadrat, cover data for species $(\mathrm{C} i)$ of the same genus were pooled into values for that genus, generating the 44 variables. The similarity percentages routine (SIMPER) was used to define those macroalgal genera that most contributed to the observed dissimilarities among sites. nMDS and SIMPER were conducted using the Primer v6 Package (CLARKE; GORLEY, 2006).

Multivariate PERMANOVA followed by post hoc tests (PERMANOVA pairwise comparisons) were then conducted to test the hypothesis that the sites differed regarding the overall percent cover of macroalgal genera. The multivariate data were analyzed according to a single factor design (four sites, $\mathrm{n}=3$ ) using the Bray-Curtis similarity matrix generated from the untransformed data with 999 permutations. These analyses were conducted using the FORTRAN program PERMANOVA (ANDERSON, 2005).

Finally, to determine differences among the sites with regard to the cover of those macroalgal genera that most contributed to dissimilarities, univariate analysis (permutational ANOVA) were conducted followed by a posteriori pairwise comparisons.

\section{RESULTS}

A total of 58 macroalgal species were identified, including 11 Ulvophyceae, 7 Phaeophyceae and 40 Florideophyceae (Table 1). Specimens of Gelidiaceae could not be identified to the genus level because they were not fertile; two types were classified based on the morphology of their erect portions. Dictyopteris delicatula, Sargassum vulgare, Aglaothamnion cordatum, Amphiroa fragilissima, Asparagopsis taxiformis, Centroceras sp., Ceramium vagans, Champia compressa, Gayliella sp., Hypnea spinella, Jania adhaerens, Jania capillacea and Wrangelia argus were collected within all quadrats. Other species with high frequency in the study area included Ceratodictyon variabile, Neosiphonia gorgoniae (91.7\%), Canistrocarpus cervicornis, Dasya sp. (83.3\%), Bryopsis pennata, Chondracanthus acicularis, Herposiphonia secunda f. tenella, Lomentaria corallicola and Spermothamnion nonatoi $(75 \%)$. The most abundant species in the study area was $S$. vulgare $(\mathrm{Cm} i=56.8 \pm 8.4 \%)$. Species with mean cover levels higher than 5\% were as follows: $H$. spinella $(11.3 \pm 2.0 \%)$, Laurencia dendroidea $(9.8 \pm 4.8 \%)$, C. cervicornis $(9.7 \pm 2.0 \%)$, Gayliella sp. $(6.8 \pm 2.6 \%)$, C. variabile $(6.8 \pm 1.4 \%)$ and A. taxiformis $(6.3 \pm 2.2 \%)$ (Table 1).

The total number of species varied from $24 \pm 0.6$ at IM1 to $41 \pm 3.8$ at IM2 (Fig. 2); this parameter differed significantly among the sites (Table 2), mainly because of the higher values at IM2 than at the other sites. Total cover varied from $140.3 \pm 28.9 \%$ at IM1 to $172.2 \pm 46.4 \%$ at IM2 (Fig. 2). Pielou's evenness indexes were also similar among sites (Fig. 2 ), ranging from $0.6 \pm 0.1$ (IM1, BP3) to $0.7 \pm 0.1$ (IM2, BP4). Total cover and evenness did not differ significantly among sites (Table 2). Shannon-Weiner diversity indexes were significantly different among sites (Table 2), driven by the higher values at IM2 $(3.6 \pm 0.3)$ and BP4 $(3.5 \pm 0.3)$ than at BP3 $(2.8 \pm 0.2)$ (Fig. 2).

The biplot based on the cover data of the macroalgal genera grouped quadrats from different sites with their replicates; BP3 quadrats were the most similar and BP4 quadrats were the most dissimilar from the quadrats of the other sites (Fig. 3). Sites were significantly different with regard to the cover multivariate data. Post hoc pairwise tests distinguished all sites from each other (Table 3). According to SIMPER, the macroalgae that most contributed to the dissimilarities of cover between the sites (contribution $>5 \%$ ) were as follows: Sargassum, Laurencia, Wrangelia, Canistrocarpus, Asparagopsis, Hypnea, Ceratodictyon, Gayliella, Spyridia and Chondria. Sargassum was the major contributor to the observed dissimilarities among the sites (Table 4).

Significant differences among sites were recorded for nearly all of the macroalgal genera that most contributed to the observed dissimilarities, except for Sargassum and Ceratodictyon (Table 5, Fig. 4). The covers of Laurencia (Fig. 4b) and Asparagopsis (Fig. 4f) were significantly higher at BP4 than at BP3 and IM2. The cover of Hypnea (Fig. $4 \mathrm{~g}$ ) was significantly higher at IM1 than at BP3. Gayliella discriminated BP4 from the other sites (Fig. 4c). For Chondria (Fig. 4j), the differences among sites were largely driven by the higher cover at IM2 than at BP4. For Canistrocarpus (Fig. 4d), post hoc pairwise tests did not detect differences among sites. Although variable, high covers of Spyridia (Fig. 4e) and Wrangelia (Fig. 4i) distinguished IM2 and BP3, respectively, from the other sites. 
Table 1. List of species of Ulvophyceae, Phaeophyceae and Florideophyceae recorded at the four sampling sites at the Tamoios Ecological Station, with their frequency of occurrence ( $\mathrm{F} i$ ) and mean cover $(\mathrm{Cm} i)$ in the sampling units $(\mathrm{n}=12)$. Species names and authors were based on Algaebase (http://www.algaebase.org) (GUIRY; GUIRY, 2014).

\begin{tabular}{|c|c|c|}
\hline SPECIES & $\mathbf{F i}$ & $\mathbf{C m} i$ \\
\hline \multicolumn{3}{|l|}{ Ulvophyceae } \\
\hline Boodlea composita (Harvey) F.Brand & 8.3 & 0.0 \\
\hline Bryopsis corymbosa J.Agardh & 25.0 & 0.1 \\
\hline Bryopsis pennata J.V.Lamouroux & 75.0 & 1.8 \\
\hline Caulerpella ambigua (Okamura) Prud'homme van Reine \& Lokhorst & 16.7 & 0.0 \\
\hline Chaetomorpha aerea (Dillwyn) Kützing & 25.0 & 0.0 \\
\hline Chaetomorpha minima F.S.Collins \& Hervey & 8.3 & 0.0 \\
\hline Cladophora brasiliana G.Martens & 8.3 & 0.0 \\
\hline Cladophora dalmatica Kützing & 41.7 & 0.0 \\
\hline Cladophora vagabunda (Linnaeus) Hoek & 8.3 & 0.0 \\
\hline Cladophoropsis membranacea (Hofman Bang ex C.Agardh) Børgesen & 25.0 & 0.0 \\
\hline Codium isthmocladum Vickers & 8.3 & 0.0 \\
\hline \multicolumn{3}{|l|}{ Phaeophyceae } \\
\hline Canistrocarpus cervicornis (Kützing) De Paula \& De Clerck & 83.3 & 9.7 \\
\hline Dictyopteris delicatula J.V.Lamouroux & 100.0 & 4.0 \\
\hline Dictyota ciliolata Sonder ex Kützing & 16.7 & 0.2 \\
\hline Feldmannia indica (Sonder) Womersley \& A.Bailey & 58.3 & 0.0 \\
\hline Padina gymnospora (Kützing) Sonder & 25.0 & 0.4 \\
\hline Sargassum vulgare C.Agardh & 100.0 & 56.8 \\
\hline Sphacelaria tribuloides Meneghini & 50.0 & 0.0 \\
\hline \multicolumn{3}{|l|}{ Florideophyceae } \\
\hline Acanthophora spicifera (M.Vahl) Børgesen & 16.7 & 0.3 \\
\hline Aglaothamnion cordatum (Børgesen) Feldmann-Mazoyer & 100.0 & 1.3 \\
\hline Amphiroa brasiliana Decaisne & 8.3 & 0.5 \\
\hline Amphiroa fragilissima (Linnaeus) J.V.Lamouroux & 100.0 & 3.9 \\
\hline Anotrichium tenue (C.Agardh) Nägeli & 16.7 & 0.0 \\
\hline Antithamnion cruciatum (C.Agardh) Nägeli & 25.0 & 0.1 \\
\hline Antithamnionella breviramosa (E.Y.Dawson) Wollaston & 16.7 & 0.0 \\
\hline Asparagopsis taxiformis (Delile) Trevisan de Saint-Léon & 100.0 & 6.3 \\
\hline Centroceras sp. & 100.0 & 0.2 \\
\hline Ceramium brevizonatum H.E.Petersen & 8.3 & 0.0 \\
\hline Ceramium comptum Børgesen & 8.3 & 0.0 \\
\hline Ceramium luetzelburgii O.C.Schmidt & 8.3 & 0.0 \\
\hline Ceramium vagans P.C.Silva & 100.0 & 0.2 \\
\hline Ceratodictyon variabile (J.Agardh) R.E.Norris & 91.7 & 6.8 \\
\hline Champia compressa Harvey & 100.0 & 2.3 \\
\hline Champia parvula (C.Agardh) Harvey & 41.7 & 0.9 \\
\hline Chondracanthus acicularis (Roth) Fredericq & 75.0 & 1.7 \\
\hline Chondria atropurpurea Harvey & 25.0 & 0.8 \\
\hline Chondria curvilineata F.S.Collins \& Hervey & 33.3 & 0.3 \\
\hline Chondria polyrhiza F.S.Collins \& Hervey & 33.3 & 1.8 \\
\hline Chondria sp. & 25.0 & 0.2 \\
\hline Dasya sp. & 83.3 & 1.4 \\
\hline Diplothamnion tetrastichum A.B.Joly \& Yamaguishi & 25.0 & 0.2 \\
\hline Dohrniella antillarum var. brasiliensis A.B.Joly \& Ugadim & 16.7 & 0.0 \\
\hline Gayliella sp. & 100.0 & 6.8 \\
\hline Gelidiella ligulata E.Y.Dawson & 58.3 & 2.6 \\
\hline Gelidiaceae Tipo I & 25.0 & 0.2 \\
\hline Gelidiaceae Tipo II & 33.3 & 0.6 \\
\hline Herposiphonia secunda (C.Agardh) Ambronn & 25.0 & 0.3 \\
\hline Herposiphonia secunda f. tenella (C. Agardh) M.J.Wynne & 75.0 & 0.1 \\
\hline Hypnea spinella (C. Agardh) Kützing & 100.0 & 11.3 \\
\hline Jania adhaerens J.V.Lamouroux & 100.0 & 3.9 \\
\hline Jania capillacea Harvey & 100.0 & 3.9 \\
\hline Laurencia caduciramulosa Masuda \& Kawaguchi & 50.0 & 3.1 \\
\hline Laurencia dendroidea J.Agardh & 41.7 & 9.8 \\
\hline Lomentaria corallicola Børgesen & 75.0 & 0.4 \\
\hline Lophocladia trichoclados (C.Agardh) F.Schmitz & 25.0 & 1.0 \\
\hline Neosiphonia gorgoniae (Harvey) S.M.Guimarães \& M.T.Fujii & 91.7 & 0.5 \\
\hline Neosiphonia sertularioides (Grateloup) K.W.Nam \& P.J.Kang & 25.0 & 0.1 \\
\hline Parviphycus trinitatensis (W.R.Taylor) M.J.Wynne & 16.7 & 0.3 \\
\hline Spermothamnion nonatoi A.B.Joly & 75.0 & 1.7 \\
\hline Spyridia hypnoides (Bory de Saint-Vincent) Papenfuss & 25.0 & 2.6 \\
\hline Wrangelia argus (Montagne) Montagne & 100.0 & 4.8 \\
\hline
\end{tabular}




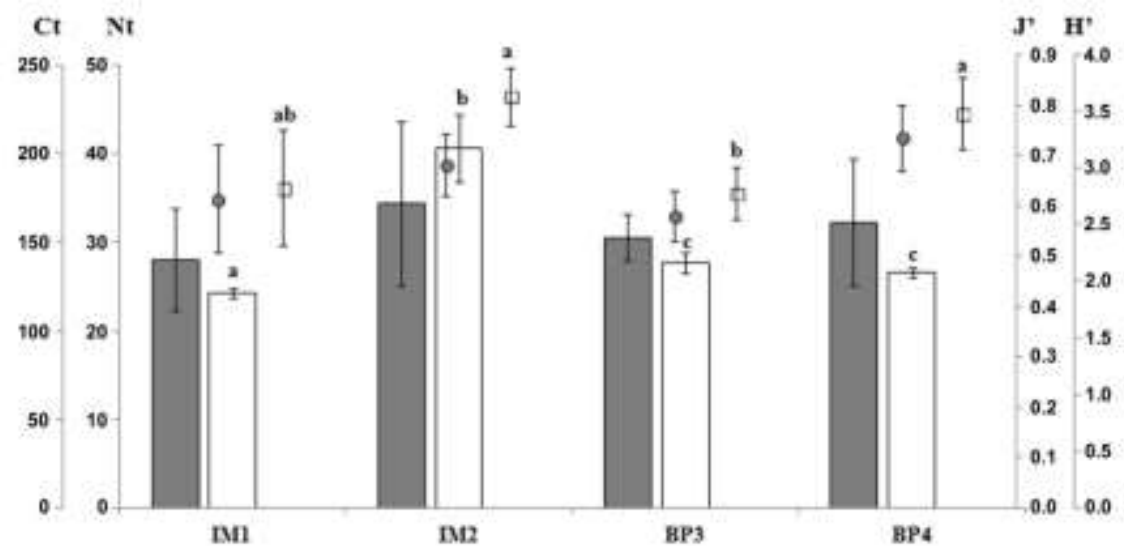

Fig. 2. Analytic parameters for each sampling site: total number of species (Nt - white bars); total cover ( $\mathrm{Ct}$ - grey bars); evenness index ( $\mathrm{J}^{\prime}$ - grey circles); diversity index $\left(\mathrm{H}^{\prime}-\right.$ white squares). Differences detected by post hoc tests (PERMANOVA pairwise comparisons) are indicated by different letters. Arithmetic means and standard deviations $(n=3)$. Imboassica=IM; Búzios Pequena=BP; Sites=1, 2, 3, 4.

Table 2. Univariate analysis (permutational ANOVA) used to investigate significant differences among the sites regarding total number of species $(\mathrm{Nt})$, total cover $(\mathrm{Ct})$, Shannon-Weiner diversity index $\left(\mathrm{H}^{\prime}\right)$; Pielou's evenness index $\left(\mathrm{J}^{\prime}\right)$. All univariate tests were analyzed according to a single factor design (four sites, $n=3$ ) based on Bray-Curtis similarity matrices generated from untransformed data with 999 permutations. Significance is indicated by asterisks * $(\mathrm{P}<0.05)$. The degrees of freedom in the source $=\mathrm{df}$; sum of squares due to the source $=\mathrm{SS}$; mean sum of squares due to the source=MS; F-statistic=F; permutation $\mathrm{P}$-value=P(perm).

\begin{tabular}{|c|c|c|c|c|c|c|c|c|c|}
\hline Source & df & SS & MS & $\bar{F}$ & $\begin{array}{l}\text { (perm) } \\
\text { (p) }\end{array}$ & SS & MS & $\bar{F}$ & $\overline{P(\mathbf{P}(\text { perm })}$ \\
\hline & & $\mathbf{N t}$ & & & & & $\mathbf{H}^{\prime}$ & & \\
\hline Sites & 3 & 1099.9 & 366.6 & 53.4 & $0.002 *$ & 449.6 & 149.9 & 4.7 & $0.04 *$ \\
\hline Residual & 8 & 54.9 & 6.9 & & & 252.5 & 31.6 & & \\
\hline \multirow[t]{2}{*}{ Total } & 11 & 1154.9 & & & & 702.1 & & & \\
\hline & & $\mathbf{C t}$ & & & & & J' & & \\
\hline Sites & 3 & 144.9 & 48.3 & 0.5 & 0.73 & 296.5 & 98.8 & 3.0 & 0.128 \\
\hline Residual & 8 & 848.9 & 106.1 & & & 264.0 & 33.0 & & \\
\hline Total & 11 & 993.7 & & & & 560.5 & & & \\
\hline
\end{tabular}




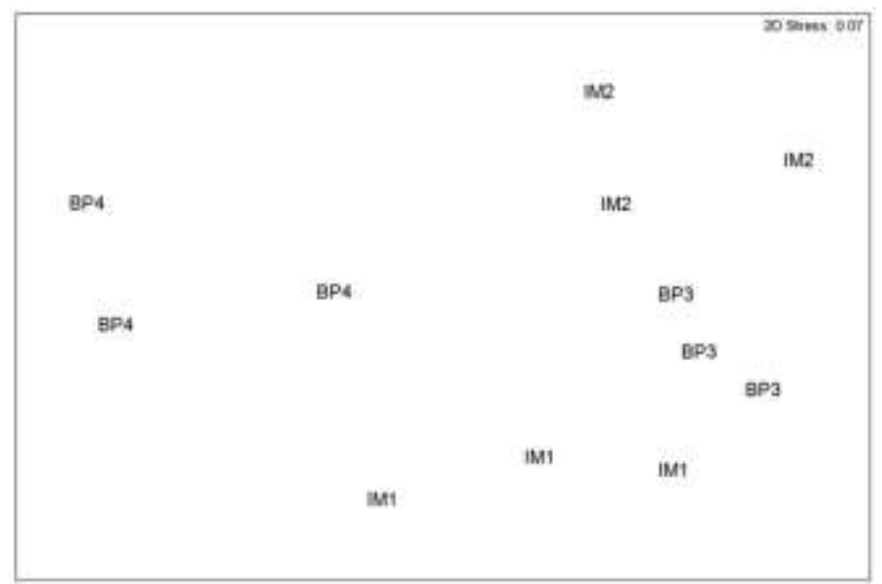

Fig. 3. nMDS biplot of sampling units (12), based on the cover of macroalgal genera (44 variables). Bray-Curtis dissimilarity matrix generated from untransformed data. Imboassica=IM; Búzios Pequena=BP; Sites=1, 2, 3, 4.

Table 3. Multivariate PERMANOVA followed by post hoc tests (PERMANOVA pairwise comparisons), used to test the hypothesis that the sites differed regarding the overall percent cover of macroalgal genera. The multivariate data were analyzed according to a single factor design (four sites, $n=3$ ) based on Bray-Curtis similarity matrices generated from untransformed data with 999 permutations. Significance is indicated by asterisks $*(\mathrm{P}<0.05)$. The degrees of freedom in the source $=\mathrm{df}$; sum of squares due to the source $=\mathrm{SS}$; mean sum of squares due to the source $=\mathrm{MS}$; F-statistic $=F$; $t$-statistic=t; permutation $\mathrm{P}$-value $=\mathrm{P}($ perm $)$; Monte Carlo asymptotic P-value=P(MC). Imboassica Island=IM; Búzios Pequena Island=BP; Sites=1, 2, 3, 4.

\begin{tabular}{lcllll}
\hline \hline Source & df & SS & MS & F & P(perm) \\
\hline Sites & 3 & 8388,7 & 2796,2 & 6,8 & $0,001^{*}$ \\
Residual & 8 & 3301,4 & 412,7 & & \\
Total & 11 & 11690,1 & & \\
\hline Pair-wise a posteriori comparisons & & \\
\hline Groups & $\mathbf{t}$ & P(MC) & & \\
(IM1, IM2) & 2,1 & $0,04^{*}$ & & \\
(IM1, BP3) & 2,1 & $0,033^{*}$ & & \\
(IM1, BP4) & 2,2 & $0,033^{*}$ & & \\
(IM2, BP3) & 2,6 & $0,013^{*}$ & & \\
(IM2, BP4) & 2,9 & $0,006^{*}$ & & \\
(BP3, BP4) & 3,9 & $0,006^{*}$ & & \\
\end{tabular}


Table 4. Contributions of macroalgal genera to the dissimilarities among sites, determined by SIMPER analysis $(\mathrm{n}=3)$. Only the top five contributors are shown. Average dissimilarities among sites are parenthesized. 'Contr. \%' refers to the contribution of each genus to differences between sites, and 'Cum. \%' is a running total of the contribution to the observed dissimilarity. Imboassica Island=IM; Búzios Pequena Island $=\mathrm{BP} ;$ Sites $=1,2,3,4$.

\begin{tabular}{lll}
\hline \hline & Contr. $\%$ & Cum. \\
Groups IM1 \& IM2 (46\%) & & \\
\hline Sargassum & 20.77 & 20.77 \\
Canistrocarpus & 8.29 & 29.06 \\
Asparagopsis & 7.61 & 36.66 \\
Spyridia & 6.9 & 43.56 \\
Chondria & 6.75 & 50.31 \\
\hline Groups IM1 \& BP3 (39\%) & & \\
Sargassum & 25.49 & 25.49 \\
Wrangelia & 11.6 & 37.08 \\
Asparagopsis & 9.94 & 47.02 \\
Hypnea & 9.33 & 56.34 \\
Ceratodictyon & 8.38 & 64.72 \\
\hline Groups IM1 \& BP4 (51\%) & & \\
Sargassum & 25.77 & 25.77 \\
Laurencia & 16.83 & 42.6 \\
Hypnea & 10.8 & 53.4 \\
Canistrocarpus & 10.16 & 63.56 \\
Gayliella & 7.94 & 71.5 \\
\hline Groups IM2 \& BP3 (38\%) & & \\
Sargassum & 20.42 & 20.42 \\
Wrangelia & 10.3 & 30.72 \\
Ceratodictyon & 8.62 & 39.34 \\
Spyridia & 8.12 & 47.46 \\
Canistrocarpus & 6.38 & 53.84 \\
\hline Groups IM2 \& BP4 (57\%) & & \\
Sargassum & 20.96 & 20.96 \\
Laurencia & 14.83 & 35.79 \\
Gayliella & 9.68 & 45.47 \\
Asparagopsis & 6.27 & 51.74 \\
Spyridia & 5.25 & 56.99 \\
\hline Groups BP3 \& BP4 (57\%) & & \\
Sargassum & 27.43 & 27.43 \\
Laurencia & 13.6 & 41.03 \\
Gayliella & 10.3 & 51.33 \\
Wrangelia & & \\
Asparagopsis & & \\
\hline & & \\
\hline
\end{tabular}

Table 5. Univariate analysis (permutational ANOVA) used to determine differences among the sites with regard to the cover of those macroalgal genera that most contributed to dissimilarities. The univariate data were analyzed according to a single factor design (four sites, $n=3$ ) based on Bray-Curtis similarity matrices generated from untransformed data with 999 permutations. Significance is indicated by asterisks $*(\mathrm{P}<0.05)$. The degrees of freedom in the source=df; sum of squares due to the source=SS; mean sum of squares due to the source $=$ MS; F-statistic $=F$; permutation $P$-value $=P($ perm $)$.

\begin{tabular}{|c|c|c|c|c|c|c|c|c|c|}
\hline Source & df & SS & MS & $\mathbf{F}$ & $\mathbf{P}($ perm $)$ & SS & MS & $\mathbf{F}$ & $\mathbf{P}$ (perm) \\
\hline & & \multicolumn{4}{|c|}{ a) Sargassum } & \multicolumn{4}{|l|}{ f) Asparagopsis } \\
\hline Sites & 3 & 4550.9 & 1517.0 & 2.9 & 0.066 & 19740.5 & 6580.2 & 4.2 & $0.017 *$ \\
\hline Residual & 8 & 4233.7 & 529.2 & & & 12401.3 & 1550.2 & & \\
\hline \multirow[t]{2}{*}{ Total } & 11 & 8784.6 & & & & 32141.8 & & & \\
\hline & & \multicolumn{4}{|c|}{ b) Laurencia } & g) Hypnea & & & \\
\hline Sites & 3 & 10846.9 & 3615.6 & 2.8 & $0.013^{*}$ & 6270.7 & 2090.2 & 2.6 & $0.012 *$ \\
\hline Residual & 8 & 10151.6 & 1268.9 & & & 6525.3 & 815.7 & & \\
\hline \multirow[t]{2}{*}{ Total } & 11 & 20998.5 & & & & 12796.0 & & & \\
\hline & & \multicolumn{4}{|c|}{ c) Gayliella } & \multicolumn{4}{|c|}{ h) Ceratodictyon } \\
\hline Sites & 3 & 21656.9 & 7219.0 & 7.5 & $0.001 *$ & 6640.2 & 2213.4 & 1.7 & 0.086 \\
\hline Residual & 8 & 7735.5 & 966.9 & & & 10139.7 & 1267.5 & & \\
\hline \multirow[t]{2}{*}{ Total } & 11 & 29392.4 & & & & 16780.0 & & & \\
\hline & & \multicolumn{4}{|c|}{ d) Canistrocarpus } & \multicolumn{4}{|l|}{ i) Wrangelia } \\
\hline Sites & 3 & 13230.7 & 4410.2 & 3.7 & $0.012 *$ & 15138.8 & 5046.3 & 4.4 & $0.012^{*}$ \\
\hline Residual & 8 & 9436.0 & 1179.5 & & & 9072.6 & 1134.1 & & \\
\hline Total & 11 & 22666.7 & & & & 24211.4 & & & \\
\hline & & e) Spyridia & & & & j) Chondria & & & \\
\hline Sites & 3 & 18502.2 & 6167.4 & 9.3 & $0.016^{*}$ & 21488.3 & 7162.8 & 4.1 & $0.011^{*}$ \\
\hline Residual & 8 & 5330.4 & 666.3 & & & 13983.6 & 1748.0 & & \\
\hline Total & 11 & 23832.6 & & & & 35472.0 & & & \\
\hline
\end{tabular}



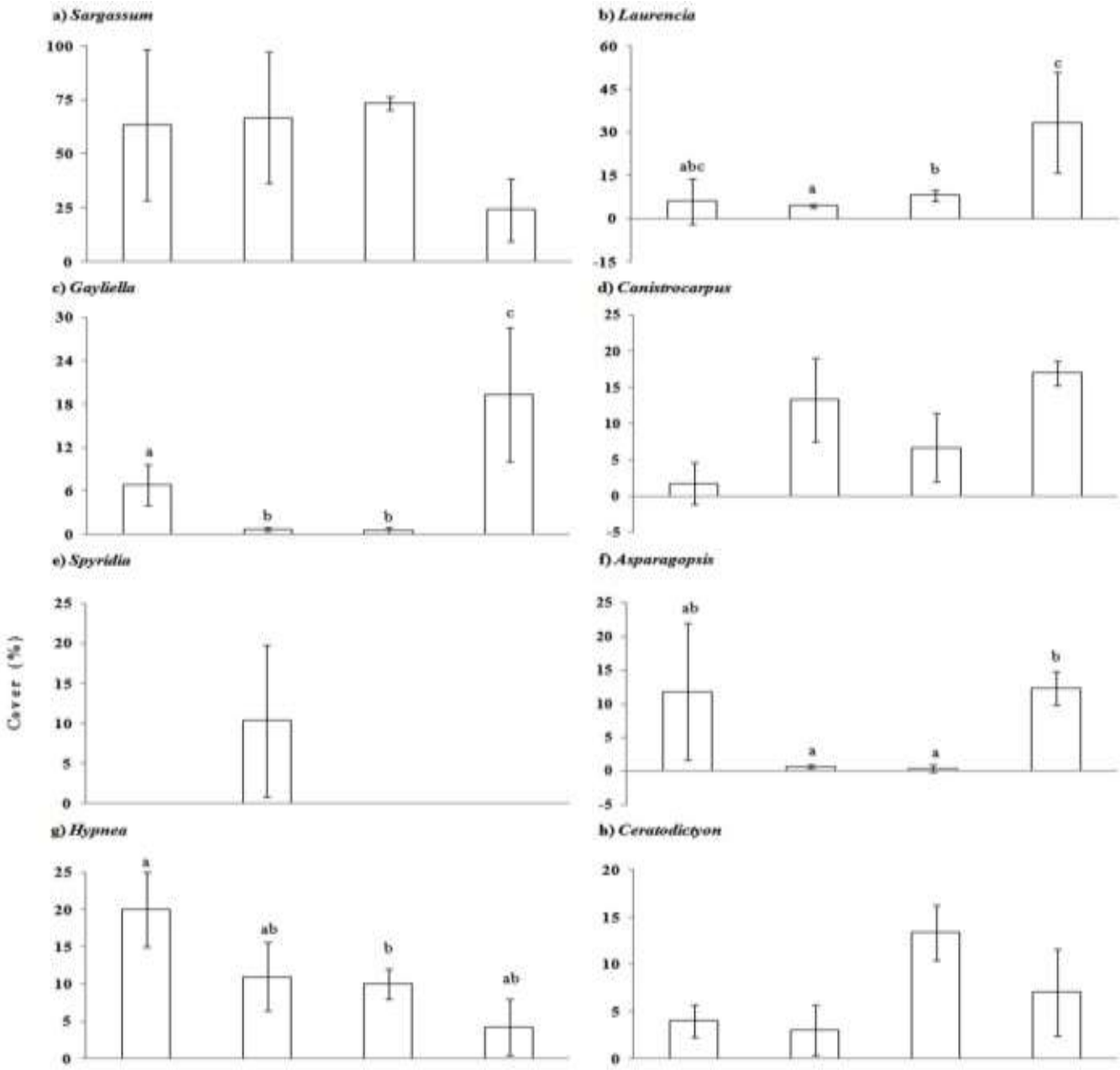

i) Wrangelia
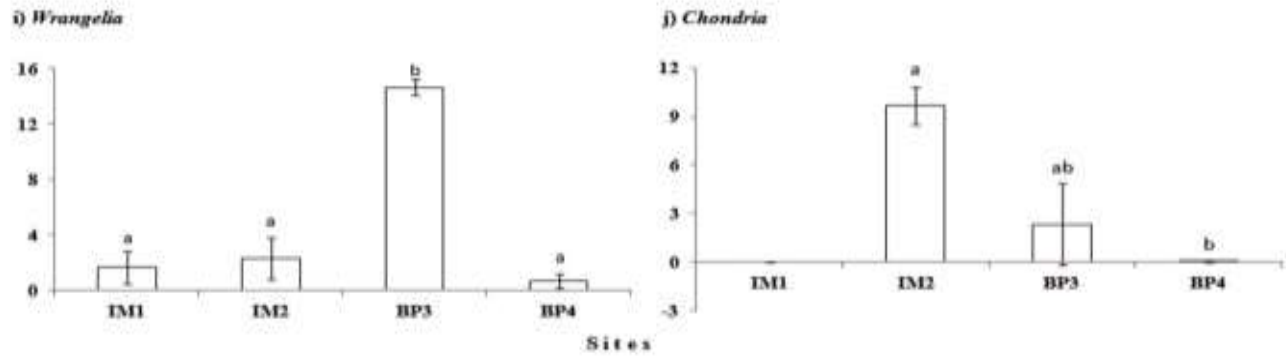

Fig. 4. Cover of the ten macroalgal genera that most contributed to dissimilarities among sites $(\mathrm{n}=3)$. Differences detected by post hoc tests (PERMANOVA pairwise comparisons) are indicated by different letters. Arithmetic means and standard deviations $(n=3)$. Imboassica $=$ IM; Búzios Pequena = BP; Sites = 1, 2, 3, 4 . 


\section{Discussion}

The structure of the shallow macroalgal assemblages of two islands in the TES was assessed for the first time in this study. The applied destructive sampling method enabled us to describe the qualitative and quantitative structure of these assemblages during the summer. The results of this study, which report analytic and synthetic parameters such as the total number of species, mean cover of species and diversity indexes, may provide a baseline for future comparisons.

The macroalgal species composition of the shallow subtidal habitat of the islands is similar in some respects to those observed in other surveys previously conducted in Ilha Grande Bay (FALCÃO et al., 1992; PEDRINI et al., 1994; GESTINARI et al., 1998; BRITO et al., 2002; SZÉCHY; NASSAR, 2005; FIGUEIREDO; TÂMEGA, 2007) and in other locations along the coasts of Rio de Janeiro and São Paulo States (SZÉCHY; PAULA, 2000a; AMADO FILHO et al., 2003, 2006; MACHADO et al., 2011). In those locations, the most representative order by number of species was Ceramiales, and the most frequent species were $H$. spinella, A. taxiformis, $D$. delicatula and $J$. adhaerens, typically associated with Sargassum beds.

The shallow macroalgal assemblages of the TES were characterized by the dominance of $S$. vulgare. Sargassum dominance in shallow rocky communities is well documented along the southeastern Brazilian coast (SZÉCHY; PAULA, 2000b; AMADO FILHO et al., 2003, 2006; FALCÃO; SZÉCHY, 2005). Sargassum beds constitute an important link between benthic primary producers and several levels of consumers (DUBIASKI-SILVA; MASUNARI, 2008; JACOBUCCI et al., 2009). The abundance of brown algae in the benthic communities, mainly Sargassum, suggests that the rocky shores of the study area had not been subjected to organic pollution (CECERE et al., 1991; BERCHEZ; OLIVEIRA, 1992; CORMACI; FURNARI, 1999; COLEMAN et al., 2008; MARINS et al., 2008).

The high number of macroalgal species $(\mathrm{Nt})$ at IM2 was due to the exclusive occurrence of 14 species, most of them filamentous. At this site, the high cover of $S$. vulgare provided a substrate for other macroalgae, supporting the presence of more filamentous epiphytes (SZÉCHY; PAULA, 1997). The presence or absence of species in the quadrats may be caused by epibiosis and other complex interactions among species, depending on characteristics such as their life history and phenology and the environmental conditions (BENEDETTI-CECCHI, 2000; MOHRING et al., 2013). Environmental conditions can benefit the reproduction, dispersion and recruitment of macroalgal species in different ways (LOBBAN; HARRISON, 1997), resulting in the continuous proliferation and disappearance of species, most of them ephemeral, at small temporal scales (KAREZ et al., 2004; PHILLIPS, 2006).

The higher diversity indexes at IM2 and BP4 may be related to the intermediary disturbance hypothesis (CONNELL, 1978), as both sites were considered as moderately exposed to wave action. Generally, moderate disturbances promote higher diversity indexes, although extreme disturbances (high or low water movements) promote low diversity (COLLINGS; CHESHIRE, 1998). However, the higher numbers of species and diversity indexes observed at IM2 and BP4 were likely artifacts of the sampling strategy. Further studies should employ temporal sampling at different scales.

No structural patterns could be defined for the macroalgal assemblages of the islands studied. A remarkable heterogeneity was observed in the shallow subtidal rocky bottom communities of the different sites, as shown by the average dissimilarities between the sites of the two islands in relation to the cover of macroalgal genera (see Table 4). Other studies on nearshore benthic communities have found that the distribution and abundance of benthic organisms can vary depending on the island habitat (VROOM et al., 2010), and additional studies have emphasized the influence of spatial scale on that variability (BENEDETTI-CECCHI, 2001; SANGIL et al., 2011). According to the literature, different physical and biological factors can shape the structure of macroalgal assemblages, including wave action (BUSTAMANTE; BRANCH, 1996), substratum heterogeneity, light availability (KENDRICK et al., 1999; TOOHEY et al., 2007), predation (MENGE; LUBCHENCO, 1981), competition (OLSON; LUBCHENCO, 1990) and facilitation (MENGE, 2000). The present study, however, did not aim to determine the causal factors underlying the described structural differences.

Although only a small proportion of the TES area occupied by rocky bottoms was studied, sites of the same island showed considerable average dissimilarities (see Table 4); in some cases, a site was more dissimilar to the other site on the same island than to the sites on the other island. Additionally, the abundances of some of the macroalgal genera that most contributed to the dissimilarities among sites were significantly different between sites on the same island (Fig. 4). This pattern of variability, which may be related to patchiness (HARTNOLL; HAWKINS, 1985), is in agreement with previous reports that have described greater variability at small spatial scales (MENGE; OLSON, 1990; FRASCHETTI et al., 2005). This variability emphasizes that different 
spatial scales should be considered in monitoring the rocky bottom communities of Ilha Grande Bay.

The present study contributes to the available knowledge of the rocky bottom communities of islands in the TES. The characterization of the structure and dynamics of macroalgal assemblages should be considered an overarching priority for the conservation of this threatened marine protected area, as such knowledge promotes a better understanding of the ecological processes that shape the rocky shore communities and provides a baseline for evaluating ecological change over time.

\section{ACKNOWLEDGMENTS}

The authors are thankful to Martha BökerTorres and Maria Beatriz B. B. Barreto for confirming the identification of Chondria curvilineata and Ceramium luetzelburgii, respectively. This research was financially supported by the Conselho Nacional de Desenvolvimento Científico e Tecnológico - CNPq under grant No 144632/2010-1, which provided an MSc. scholarship for the first author.

\section{REFERENCES}

AIRAME, S.; DUGAN, J. E.; LAFFERTY, K. D.; LESLIE, H.; MCARDLE, D. A.; WARNER, R. R. Applying ecological criteria to marine reserve design: a case study from the California Channel Islands. Ecol. Appl., v. 13, p. $170-184,2003$.

ALHO, C. J. R.; SCHNEIDER, M.; VASCONCELLOS, L. A. Degree of threat to the biological diversity in the Ilha Grande State Park (RJ) and guidelines for conservation. Braz. J. Biol., v. 62, n. 3, p. 375-385, 2002.

AMADO FILHO, G. M.; BARRETO, M. B. B.; MARINS, B. V.; FELIX, C.; REIS, R. P. Estrutura das comunidades fitobentônicas do infralitoral da Baía de Sepetiba, RJ, Brasil. Rev. Bras. Bot., v. 26, n. 3, p. 329342, 2003.

AMADO FILHO, G. M.; HORTA, P. A.; BRASILEIRO, P. S.; BARRETO, M. B. B.; FUJII, M. T. Subtidal benthic marine algae of the marine state park of Laje de Santos (São Paulo, Brazil). Braz. J. Oceanogr., v. 54, n. 4, p. 225-234, 2006

ANDERSON, M. J. PERMANOVA: a FORTRAN computer program for permutational multivariate analysis of variance. Department of Statistics, University of Auckland, New Zealand, 2005.

BELO, W. C. O fundo marinho da Baía da Ilha Grande, RJ: evidência de ação de correntes e ondas no canal central com base em formas de fundo observadas em registros de sonar (100kHz). Rev. Bras. Geof., v. 20, n. 1, p. 1730, 2002.

BENEDETTI-CECCHI, L. Priority effects, taxonomic resolution, and the prediction of variable patterns of colonization of algae in littoral rock pools. Oecologia, v. 123 , n. 2, p. 265-274, 2000.
BENEDETTI-CECCHI, L. Variability in abundance of algae and invertebrates at different spatial scales on rocky sea shores. Mar. Ecol. Prog. Ser., v. 215, p. 79- 92, 2001.

BERCHEZ, F. A. S.; OLIVEIRA, E. C. Temporal changes in benthic marine flora of the Baía de Santos, SP, Brazil, over the last four decades. In: CORDEIRO-MARINO, M.; AZEVEDO, M. T. P.; SANT'ANNA, C. L.; TOMITA, N. Y.; PLASTINO, E. M. (Eds.). Algae and environment: a general approach. São Paulo: Sociedade Brasileira de Ficologia, CETESB, 1992. p. 120-131.

BRASIL. Decreto $\mathbf{n}^{\mathbf{0}} \mathbf{9 8 . 8 6 4}$, de 23 de janeiro de 1990. Cria a Estação Ecológica de Tamoios, e dá outras providências. Available on internet at: <http://www.planalto.gov.br/ccivil_03/decreto/19901994/D98864.htm>. Accessed 11 jan. 2012.

BRASIL. Lei $\mathbf{n}^{\circ} \mathbf{9 . 9 8 5}$, de 18 de julho de 2000 . Regulamenta o art. 225, § 1o, incisos I, II, III e VII da Constituição Federal, institui o Sistema Nacional de Unidades de Conservação da Natureza e dá outras providências. Available on internet at: <http://www.planalto.gov.br/ccivil_03/Leis/L9985.htm>. Accessed 11 jan. 2012.

BRITO, L. V. R.; SZÉCHY, M. T. M.; CASSANO, V. Levantamento taxonômico das macroalgas da zona das marés de costões rochosos adjacentes ao Terminal Marítimo Almirante Maximiano Fonseca, Baía da Ilha Grande, RJ. Atlântica, v. 24, n. 1, p. 17-26, 2002.

BUSTAMANTE, R. H.; BRANCH, G. M. Large scale patterns and trophic structure of southern African rocky shores: the roles of geographic variation and wave exposure. J. Biogeography, v. 23, n. 3, p. 339-351, 1996.

CECERE, E.; CORMACI, M.; FURNARI, G. The marine algae of Mar Piccolo, Taranto (Southern Italy): a reassessment. Bot. Mar., v. 34, p. 221-227, 1991.

CLARKE, K. R.; GORLEY, R. N. PRIMER v6: User manual: tutorial. Plymouth: PRIMER-E, 2006.

CLYNICK, B. G.; BLOCKLEY, D.; CHAPMAN, M.G. Anthropogenic changes in patterns of diversity on hard substrata: an overview. In: WAHL, M. (Ed.). Marine hard bottom communities: patterns, dynamics, diversity, and change. Berlin: Springer-Verlag (Ecological Studies 206), 2009. Chap. 17. p. 247- 256.

COLEMAN, M. A.; KELAHER, B. P.; STEINBERG, P. D.; MILLAR, A. J. K. Absence of a large brown macroalga on urbanized rocky reefs around Sydney, Australia, and evidence for historical decline. J. Phycol., v. 44, n. 4, p. 897-901, 2008.

COLlingS, G. J.; CHESHIRE, A. C. Composition of subtidal macroalgal communities of the lower gulf waters of South Australia, with references to water movement and geographical separation. Aust. J. Bot., v. 46, n. 6, p. 657-669, 1998 .

CONNELL, J. H. Diversity in tropical rain forests and coral reefs. Science, v. 199, n. 4335, p. 1302-1310, 1978.

CORMACI, M.; FURNARI, G. Changes of the benthic algal flora of the Tremiti Islands (southern Adriatic) Italy. Hydrobiologia, v. 398/399, p. 75-79, 1999.

CREED, J.C. Ecossistemas marinhos. In: BASTOS, M.; CALLADO, C. H. (Eds.). O ambiente da Ilha Grande. Rio de Janeiro: Universidade do Estado do Rio de Janeiro, Centro de Estudos Ambientais e Desenvolvimento Sustentável, 2009. Cap. 7. p. 247-298. 
CREED, J. C.; PIRES, D. O.; FIGUEIREDO, M. A. O. Biodiversidade marinha da Baía da Ilha Grande. Brasília: Ministério do Meio Ambiente (Biodiversidade 23), 2007. 417p.

DAWES, C. J.; MATHIESON, A. C. The seaweeds of Florida. Gainesville: University Press of Florida, 2008. $656 \mathrm{p}$.

DUBIASKI-SILVA, J.; MASUNARI, S. Natural diet of fishes and crabs associated with Sargassum cymosum C. Agardh, 1820 (Phaeophyta, Fucales) at Ponta das Garoupas, Bombinhas, Santa Catarina State, Brazil. J. Nat. Hist., v. 42, n. 27/28, p. 1907-1922, 2008.

FALCÃO, C.; MAURAT, M. C.; NASSAR, C. A. G.; SZÉCHY, M. T. M.; MITCHELL, G. J. P. Benthic marine flora of the northeastern and southeastern coast of Ilha Grande, Rio de Janeiro, Brazil: phytogeographic considerations. Bot. Mar., v. 35, p. 357-364, 1992.

FALCÃO, C.; SZÉCHY, M. T. M. Changes in shallow phytobenthic assemblages in southeastern Brazil, following the replacement of Sargassum vulgare (Phaeophyta) by Caulerpa scalpelliformis (Clorophyta). Bot. Mar., v. 48, n. 3, p. 208-217, 2005.

FIGUEIREDO, M. A. O.; BARRETO, M. B. B.; REIS, R. P. Caracterização das macroalgas nas comunidades marinhas da Área de Proteção Ambiental de Cairuçu, Parati, RJ- subsídios para futuros monitoramentos. Rev. Bras. Bot., v. 27, n. 1, p. 11-17, 2004.

FIGUEIREDO, M. A. O.; TÂMEGA, F. T. S. 2007. Macroalgas marinhas. In: CREED, J. C.; PIRES, D. O.; FIGUEIREDO, M. A. O. (Eds.). Biodiversidade marinha da Baía da Ilha Grande. Brasília: Ministério do Meio Ambiente, 2007. Cap. 6. p. 155-180.

FRASCHETTI, S.; TERLIZZI, A.; BENEDETTI-CECCHI, L. Patterns of distribution of marine assemblages from rocky shores: evidence of relevant scales of variation. Mar. Ecol. Prog. Ser., v. 296, p. 13-29, 2005.

GESTINARI, L. M. S.; NASSAR, C. A. G.; ARANTES, P. V. S. Algas marinhas bentônicas da Reserva Biológica Estadual da Praia do Sul, Ilha Grande, Angra dos Reis, Rio de Janeiro, Brasil. Acta Bot. Bras., v. 12, n. 1, p. $67-$ 76, 1998

GOODSELL, P. J.; UNDERWOOD, A. J. Protection of biota and the value of marine protected areas. In: WAHL, M. (Ed.). Marine hard bottom communities: patterns, dynamics, diversity, and change. Berlin: SpringerVerlag (Ecological Studies 206), 2009. Chap. 25. p. 345355 .

GUIRY, M. D.; GUIRY, G. M. AlgaeBase. World-wide electronic publication, National University of Ireland, Galway. Available on internet at: <http://www.algaebase.org>. Accessed 18 Apr. 2014.

HARTNOLL, R. G.; HAWKINS, S. J. Patchiness and fluctuations on moderately exposed rocky shores. Ophelia, v. 24, p. 53-63, 1985.

HORTA, P. A.; SALlES, J. P.; BOUZON, J. L.; SCHERNER, F.; CABRAL, D. Q.; BOUZON, Z. L. Composição e estrutura do fitobentos do infralitoral da Reserva Biológica Marinha do Arvoredo, Santa Catarina, Brasil- implicações para a conservação. Oecol. Bras., v. 12 , n. 2, p. 243-257, 2008.

JACOBUCCI, G. B.; TANAKA, M. O.; LEITE, F. P. P. Factors influencing temporal variation of a Sargassum filipendula (Phaeophyta: Fucales) bed in a subtropical shore. J. Mar. Biol. Assoc. UK, v. 89, n. 2, p. 315-321, 2009.

JOLY, A. B. Flora marinha do litoral norte do Estado de São Paulo e regiões circunvizinhas. Bolm FFLCH-USP. Botânica 21, p. 1-393, 1965.

KAREZ, R.; ENGELBERT, S.; KRAUFVELIN, P.; PEDERSEN, M. F.; SOMMER, U. Biomass response and changes in composition of ephemeral macroalgal assemblages along an experimental gradient of nutrient enrichment. Aquat. Bot., v. 78, n. 2, p. 103-117, 2004.

KENDRICK, G. A.; LAVERY, P. S.; PHILLIPS, J. C. Influence of Ecklonia radiata kelp canopy on structure of macro-algal assemblages in Marmion Lagoon, Western Australia. Hydrobiologia, v. 398/399, p. 275283, 1999.

LAGES, B. G.; FLEURY, B. G.; MENEGOLA, C.; CREED, J. C. Change in tropical rocky shore communities due to an alien coral invasion. Mar. Ecol. Prog. Ser., v. 438, p. 85-96, 2011.

LANARI, M. O.; COUTINHO, R. Reciprocal causality between marine macroalgal diversity and productivity in an upwelling area. Oikos, v. 123, n. 5, p. 630-640, 2014.

LITTLER, D. S.; LITTLER, M. M. Caribbean reef plants: an identification guide to the reef plants of the Caribbean, Bahamas, Florida and Gulf of Mexico. Washington: Offshore Graphics, 2000. 542p.

LOBBAN, C. S.; HARRISON, P. J. Seaweed ecology and physiology. Cambridge: Cambridge University Press, 1997. 366p.

MACHADO, G. E. M.; NASSAR, C. A. G.; SZÉCHY, M. T. M. Flora ficológica da região sublitorânea rasa de costões rochosos do Núcleo Picinguaba, Parque Estadual da Serra do Mar, Ubatuba, São Paulo. Acta Bot. Bras., v. 25, n. 1 , p. 71-82, 2011.

MAHIQUES, M. M.; FURTADO, V. V. Utilização da análise dos componentes principais na caracterização dos sedimentos de superfície de fundo da Baía da Ilha Grande. Bolm. Inst. Oceanogr., S. Paulo, v. 37, n.1, p. $1-19,1989$.

MARINS, B. V.; BRASILEIRO, P. S.; BARRETO, M. B. B.; NUNES, J. M. C.; YONESHIGUE-VALENTIN, Y.; AMADO FILHO, G. M. Subtidal benthic marine algae of Todos os Santos Bay, Bahia state, Brazil. Oecol. Bras., v. 12, n. 2, p. 229-242, 2008.

MENGE, B. Testing the relative importance of positive and negative effects on community structure. Trends Ecol. Evolut., v. 15, n. 2, p. 46-47, 2000.

MENGE, B. A.; LUBCHENCO, J. Community organization in temperate and tropical rocky intertidal habitats: prey refuges in relation to consumer pressure gradients. Ecol. Monograph, v. 51, n. 4, p. 429-450, 1981.

MENGE, B. A.; OLSON, A. M. Role of scale and environmental-factors in regulation of community structure. Trends Ecol. Evolut., v. 5, n. 2, p. 52-57, 1990.

MOHRING, M. B.; WERNBERG, T.; KENDRICK, G. A.; RULE, M. J. Reproductive synchrony in a habitatforming kelp and its relationship with environmental conditions. Mar. Biol., v. 160, n. 1, p. 119-126, 2013.

NORTON, T. A.; MELKONIAN, M.; ANDERSON, R. A. Algal biodiversity. Phycologia, v. 35, p. 308-326, 1996.

OLIVEIRA FILHO, E. C.; UGADIM, Y. A survey of the marine algae of Atol das Rocas (Brazil). Phycologia, v. 15, p. 421-444, 1976. 
OLSON, A.M.; LUBCHENCO, J. Competition in seaweeds: linking plant traits to competitive outcomes. J. Phycol., v. 26, n. 1, p. 1-6, 1990.

PEDRINI, A. G.; CASSANO, V.; COELHO, L. G.; LABRONICI, G. J. Macroalgas marinhas da região sob influência da Central Nuclear Almirante Álvaro Alberto, Angra dos Reis, RJ, Brasil. I: composição taxonômica. Anais do V Congresso Geral de Energia Nuclear. Rio de Janeiro, Associação Brasileira de Energia Nuclear, 1994, v. 2, p. 727-731.

PHILLIPS, J. A. Drifting blooms of the endemic filamentous brown alga Hincksia sordida at Noosa on the subtropical east Australian coast. Mar. Pollut. Bull., v. 52, n. 8, p. 962-968, 2006.

SANGIL, C.; SANSÓN, M.; AFONSO-CARRILLO, J. Spatial variation patterns of subtidal seaweed assemblages along a subtropical oceanic archipelago: thermal gradient vs herbivore pressure. Estuar. Coast. Shelf Sci., v. 94, n. 4, p. 322- 333, 2011.

SCHNEIDER, C. W.; SEARLES, R. B. Seaweeds of the Southeastern United States - Cape Hatteras to Cape Canaveral. Durham and London: Duke University Press, 1991. 569p.

STACHOWICZ, J. J.; GRAHAM, M.; BRACKEN, M. E. S.; SZOBOSZLAI, A. I. Diversity enhances cover and stability of seaweed assemblages: the role of heterogeneity and time. Ecology, v. 89, n. 11, p. 3008 3019, 2008.

SZÉCHY, M. T. M.; PAULA, E. J. Macroalgas epífitas em Sargassum (Phaeophyta, Fucales) do litoral dos estados do Rio de Janeiro e São Paulo, Brasil. Leandra, v. 12, p. 1-10, 1997.

SZÉCHY, M. T. M.; PAULA, E. J. Macroalgas associadas a bancos de Sargassum C. Agardh (Phaeophyta, Fucales) do litoral dos estados do Rio de Janeiro e São Paulo, Brasil. Hoehnea, v. 27, n. 3, p. 235-257, 2000a.

SZÉCHY, M. T. M.; PAULA, E. J. Padrões estruturais quantitativos de bancos de Sargassum (Phaeophyta Fucales) do litoral dos estados do Rio de Janeiro e São Paulo, Brasil. Rev. Bras. Bot., v. 23, n. 2, p. 121-132, 2000b.
SZÉCHY, M. T. M.; NASSAR, C. A. G. Flora ficológica bentônica da Baía de Ribeira, sul do Estado do Rio de Janeiro: avaliação após duas décadas de operação da Central Nuclear Almirante Álvaro Alberto. Anais da X Reunião Brasileira de Ficologia. Salvador. Rio de Janeiro, Museu Nacional (Série Livros, 10), 2005. p. 373-397.

SZÉCHY, M. T. M.; NASSAR, C. A. G.; FALCÃO, C.; MAURAT, M. C. S. Contribuição ao inventário das algas marinhas bentônicas de Fernando de Noronha. Rodriguésia, v. 67, n. 41, p. 53-61, 1989.

TOOHEY, B. D.; KENDRICK, G. A.; HARVEY, E. S. Disturbance and reef topography maintain high local diversity in Ecklonia radiata kelp forests. Oikos, v. 116, n. 10, p. 1618-1630, 2007.

VILLAÇA, R.; YONESHIGUE-VALENTIN, Y.; BOUDOURESQUE, C. F. Estrutura da comunidade de macroalgas do infralitoral do lado exposto da Ilha de Cabo Frio (Arraial do Cabo, RJ). Oecol. Bras., v. 12, n. 2, p. 206-221, 2008.

VROOM, P. S.; MUSBURGER, C. A.; COOPER, S. W.; MARAGOS, J. E.; PAGE-ALBINS, K. N.; TIMMERS, M. A. V. Marine biological community baselines in unimpacted tropical ecosystems: spatial and temporal analysis of reefs at Howland and Baker Islands. Biodivers. Conserv., v. 19, n. 3, p. 797-812, 2010.

WAHL, M. Epibiosis: ecology, effects and defences. In: WAHL, M. (Ed.). Marine hard bottom communities: patterns, dynamics, diversity, and change. Berlin: Springer-Verlag (Ecological Studies 206), 2009. Chap. 4, p. 61-72.

(Manuscript received 05 May 2014; revised 02 November 2014; accepted 03 November 2014) 